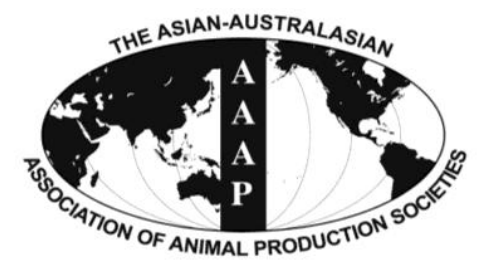

Asian-Aust. J. Anim. Sci.

Vol. 25, No. $8: 1197$ - 1204

August 2012

www.ajas.info

http://dx.doi.org/10.5713/ajas.2012.12055

\title{
Effect of Rapid Chilling on Beef Quality and Cytoskeletal Protein Degradation in M. Iongissimus of Chinese Yellow Crossbred Bulls
}

\author{
Yanwei Mao a, Yimin Zhanga, Rongrong Liang, Lulu Ren, He Zhu, Ke Li, Lixian Zhu and Xin Luo* \\ College of Food Science and Engineering, Shandong Agricultural University, \\ Tai'an, Shandong Province, 271018, China
}

\begin{abstract}
The objective of this study was to investigate the effect of rapid chilling (RC) on beef quality and the degradation of cytoskeletal proteins. Twenty Chinese Yellow crossbred bulls were selected and randomly divided into two groups. RC and conventional chilling (CC) were applied to left and right sides of the carcasses respectively after slaughtering. To determine whether electrical stimulation (ES) treatment can alleviate the potential hazard of RC on meat quality, ES was applied to one group. The effects of RC and ES were determined by meat color, shear force and cytoskeletal protein degradation postmortem (PM). The results showed that RC decreased beef tenderness at $1 \mathrm{~d}$ and $3 \mathrm{~d}$ postmortem, but had no detrimental effect on meat color. Western blotting showed that RC decreased the degradation rate of desmin and troponin-T, but the effects weakened gradually as postmortem aging extended. Degradation rates of both desmin and troponin-T were accelerated by ES. The combination of RC and ES could improve beef color, accelerate degradation rate of cytoskeletal protein and improve beef tenderness. (Key Words: Beef, Rapid Chilling, Electrical Stimulation, Cytoskeletal Protein Degradation, Chinese Yellow Crossbred Bulls)
\end{abstract}

\section{INTRODUCTION}

Chilling processes of livestock carcasses is one of the most important factors that affect product quality and is employed to ensure food safety, extend shelf-life, and reduce shrinkage (Savell et al., 2005). Conventional carcass chilling is a lengthy, energy-expensive process (Janz et al., 2001) and introduces extra microbial hazards and increases evaporative weight loss (Joseph, 1996). RC can increase production efficiency by decreasing the required chilling time and lowering evaporative loss (Janz et al., 2001). However, RC may decrease tenderness and increase the variation in tenderness, both of which influence consumer's satisfaction for beef palatability (Miller et al., 2001; Savell et al., 2005; White et al., 2006a). Many studies also reported that $\mathrm{RC}$ has detrimental effect on beef color, resulting in darker meat color (Janz et al., 2001; Aalhus et al., 2002) and reducing purchase desire of consumers.

Although China has become the third-largest beef

\footnotetext{
* Corresponding Author: Xin Luo. Tel: +86-0538-8242745, Fax: +86-0538-8242745, E-mail: luoxin@ sdau.edu.cn

a Yanwei Mao and Yimin Zhang contributed equally to this work as co-first authors.

Submitted Feb. 2, 2012; Accepted Mar. 21, 2012; Revised Apr. 4, 2012
}

producer in the world, some techniques such as electrical stimulation are not used broadly and the tenderness of beef product need to be increased urgently, so the processing technology of beef in China appeals for further improvement. The effects of RC and ES on beef quality of Chinese Yellow crossbred bulls have been reported ( $\mathrm{Li}$ et al., 2006), however, the effects on meat color have not been reported and mechanisms of tenderizing were not investigated extensively.

It is generally accepted that the degradation of the skeleton proteins plays an important role in the tenderization process (Rhee et al., 2000). Ho et al. (1996) reported that desmin and troponin-T are two of the major cytoskeletal proteins that degrade during postmortem aging. Desmin is one of the transversely running elements that links adjacent myofibrils together, and its degradation causes the loss of transversal alignment of the sarcomeres (Rhee et al., 2000). Troponin-T is part of the regulatory complex that mediates the actin-myosin interaction. The degradation of troponin-T will alter the interactions of thick and thin filaments. The degradation of these two proteins can cause fragmentation of the myofibril and loss of muscle cell integrity, and ultimately contribute to meat tenderness (Huff Lonergan et al., 2010). So the objective of this study was to evaluate the effects of RC on beef quality and to 
identify the effects of RC on the degradation of the major cytoskeletal proteins in Chinese Yellow crossbred bulls. Meanwhile, it was also investigated whether ES can alleviate the potential negative effects of $\mathrm{RC}$ on beef tenderness.

\section{MATERIALS AND METHODS}

\section{Sample processing}

Twenty Chinese Yellow crossbred bulls (Yan-bianx Simmentals) aged 18 months were selected, randomly divided into two groups and slaughtered. The mean slaughter weight was $629.0 \pm 50.3 \mathrm{~kg}$. One group was subjected to electrical stimulation (ES: $42 \mathrm{~V}, 50 \mathrm{~Hz}, 0.7 \mathrm{~A}$ for $40 \mathrm{~s}$ ) with a commercial ES unit (EST-608, Freund, Germany) immediately after bleeding. The stimulation was applied via the neck region of the carcass, using the rail as the earth. The other group that was not subjected to ES was referred to as the non-stimulated control (NS). After the split process, rapid chilling ( $\mathrm{RC}:-14 \pm 1^{\circ} \mathrm{C}$ for $2 \mathrm{~h}$, air velocity of $3 \mathrm{~m} / \mathrm{s}$, then transfer into conventional chilling to $24 \mathrm{~h}$ postmortem) was applied to the left half of the carcasses, and conventional chilling (CC: 0 to $4^{\circ} \mathrm{C}$ for $24 \mathrm{~h}$ ) was applied to the right half of the carcasses.

The experiment was undertaken following the guidelines of the Animal Ethics Committee in Shandong Agricultural University and all experimental procedures were approved by the State Scientific and Technological Commission (China, 19881114).

Samples (10 g) for SDS-PAGE analysis were removed from the M. longissimus at $2 \mathrm{~h}$ (between the 12th and 13th rib interface) postmortem by an expert butcher. After $24 \mathrm{~h}$ in the conditioning room, the carcasses were transferred to the cutting room, and the M. longissimus were excised from the carcasses. A series of small samples weighing approximately $10 \mathrm{~g}$ were prepared for SDS-PAGE analysis, and 2.54-cm-thick steaks were removed for tenderness determinations, which were vacuum packed and stored at $2 \pm 2^{\circ} \mathrm{C}$ until $7 \mathrm{~d}$ postmortem. All samples $(10 \mathrm{~g})$ collected at $2 \mathrm{~h}$ postmortem and on $1 \mathrm{~d}, 3 \mathrm{~d}$, and $7 \mathrm{~d}$ postmortem were frozen in liquid nitrogen until assayed. The steaks used for tenderness determinations were collected on $1 \mathrm{~d}, 3 \mathrm{~d}$, and 7 $\mathrm{d}$ postmortem respectively, and all were frozen immediately at $-20^{\circ} \mathrm{C}$ until assayed.

\section{Meat color and shear force measurement}

At $1 \mathrm{~d}, 3 \mathrm{~d}$ and $7 \mathrm{~d}$ postmortem, exposed the fresh meat cut surfaces to the air for $20 \mathrm{~min}$, then the color of the lean tissue was objectively evaluated (X-Rite SP62 Portable Sphere Spectrophotometer, USA) by recording CIE L*, $\mathrm{a}^{*}$, and $b^{*}$ value at three locations across the exposed surface, avoiding areas of clearly visible connective and adipose tissues with care.

Shear force measurements were carried out according to the procedures described by Luo et al. (2008). Briefly, core samples (1.27 cm diameter) were removed from each cooked steak (6 cores/steak), which were parallel to fiber orientation, and then the WBSF was measured, expressed in Newton (N).

\section{Muscle proteins preparation}

Muscle proteins were prepared from $M$. longissimus at 2 h, $1 \mathrm{~d}, 3 \mathrm{~d}$, and $7 \mathrm{~d}$ postmortem muscle. Approximately 0.4 $\mathrm{g}$ of minced muscles and $4 \mathrm{ml}$ of extract buffer (EB: $2 \%$ SDS, $10 \mathrm{mmol} / \mathrm{L} \mathrm{Na3PO4,} \mathrm{pH}$ 7.0) were ground using a mortar and pestle and then filtered to remove the large tissues. The protein concentration was determined using the biuret assay. The muscle proteins were stored at $-30^{\circ} \mathrm{C}$ before use.

\section{SDS-PAGE}

SDS-PAGE and Western blotting were conducted according to a modification of the method described by Sun et al. (2008). SDS-PAGE was performed using an EPS-301 (Amersham, USA). Two gel systems $(16 \mathrm{~cm}$ high $\times 16 \mathrm{~cm}$ wide $\times 1.5 \mathrm{~mm}$ thick) consisting of $12.5 \%$ separating gel (acrylamide: $\mathrm{N}, \quad \mathrm{N}^{\prime}$-methylenebisacrylamide $=36.5: 1$, $\mathrm{wt} / \mathrm{wt}$ ) and 5\% stacking gel (acrylamide: $\mathrm{N}, \mathrm{N}^{\prime}-$ methylenebisacrylamide $=36.5: 1, \mathrm{wt} / \mathrm{wt}$ ) were used for the protein separation. The running buffer used in both the upper and lower buffer chambers consisted of $25 \mathrm{mM}$ Tris, $192 \mathrm{mM}$ glycine, and $0.1 \%$ SDS. The gel was run at $40 \mathrm{~mA}$ for $4 \mathrm{~h}$ to detect postmortem changes in desmin and troponin- $\mathrm{T}$.

\section{Western blotting analyses}

After performing the SDS-PAGE, proteins were transferred from the separating gel to a polyvinylidene fluoride (PVDF) membrane (Immobilon-P, Millipore Corporation, CHELMSFORD, MA, USA) using EPS2A200 (Amersham, USA). The transfer buffer (15\% methanol, 20 $\mathrm{mM}$ Tris, and $192 \mathrm{mM}$ glycine) was used for the detection of desmin and troponin-T. The electric current used is the membrane area multiplied by 0.8 , with a constant current transfer of $70 \mathrm{~min}$. After the transfer, the membranes were blocked with $5 \%(\mathrm{wt} / \mathrm{vol})$ skim milk powder in TTBS solution (30 mM Tris, pH 7.5, $500 \mathrm{mM} \mathrm{NaCl}, 0.05 \%$ Tween -20) for $2 \mathrm{~h}$ at room temperature with gentle rocking, and then washed three times with TTBS solution for $10 \mathrm{~min}$ at room temperature. Monoclonal antibodies (Sigma Chemical Co., USA) against desmin (clone DE-U-10) and troponin-T (clone JLT-12) were used as the primary antibodies. Each membrane was incubated with a primary antibody in 5\% skim milk powder in TTBS solution for $2.5 \mathrm{~h}$ at room 


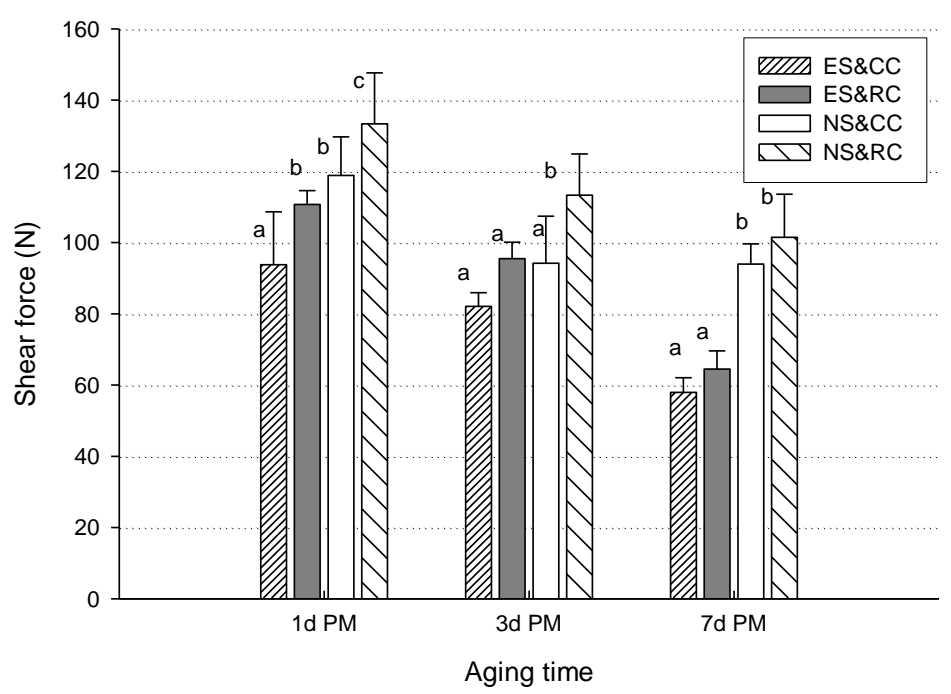

Figure 1. Shear force of M. longissimus at 1, 3, and $7 \mathrm{~d}$ post-mortem with different treatments. CC\&ES: carcasses which were conventionally chilled and electrically stimulated after slaughter; RC\&ES: carcasses which were rapidly chilled and electrically stimulated after slaughter; CC\&NS: carcasses which were conventionally chilled and not electrically stimulated after slaughter; RC\&NS: carcasses which were rapidly chilled and not electrically stimulated after slaughter.

temperature and washed three times in TTBS for $10 \mathrm{~min}$ each time. Incubation with the secondary antibody (1:4,000, goat anti-mouse IgG alkaline phosphatase-conjugated secondary antibody, Sigma Chemical Co., USA) in TTBS was done for $2 \mathrm{~h}$ at room temperature, and the membrane was washed three times with TTBS for $10 \mathrm{~min}$ each time. Then the membrane was rinsed with an alkaline phosphatase buffer $(0.1 \mathrm{M}$ Tris, $\mathrm{pH} 9.5,0.1 \mathrm{M} \mathrm{NaCl}, 50$ $\mathrm{mM} \mathrm{MgCl}, 1 \mathrm{mM} \mathrm{ZnCl}_{2}$ ) for $5 \mathrm{~min}$ at $25^{\circ} \mathrm{C}$. The bound antibodies were visualized by incubating the membranes with the alkaline phosphatase substrate BCIP/NBT, and the membrane was rinsed with distilled water to stop reaction.

\section{Data processing}

The effects of ES and RC on meat color and shear force value were evaluated using the analysis of variance. The means of variable among different treatments were compared using the Student-Newman-Keuls test $(\mathrm{p}<0.05)$. All the analyses were performed by SAS 9.0. Figure 1 was fitted to the data (mean value \pm STD of each treatment) using the SigmaPlot computer package.

\section{RESULTS AND ANALYSES}

\section{Meat color}

In the present study, meat color was not deteriorated by $\mathrm{RC}(\mathrm{p}<0.05)$, but ES increased $\mathrm{L}^{*}$ value at $1 \mathrm{~d}, 3 \mathrm{~d}$ and $7 \mathrm{~d}$ (p>0.05) (Table 1). So it can be concluded that $\mathrm{RC}$ at $-15^{\circ} \mathrm{C}$, $2 \mathrm{~h}$ had no detrimental effect on meat color. ES could result in brighter beef.

In contrast to the present study, Janz et al. (2001) reported that $\mathrm{RC}$ resulted in a darker bison meat color. The

Table 1. Effects of different treatments on meat color of M. longissimus at 1, 3, and $7 \mathrm{~d}$ postmortem

\begin{tabular}{cccccc}
\hline & & ES\&CC & ES\&RC & NS\&CC & NS\&RC \\
\hline L $^{*}$ & $1 \mathrm{~d}$ PM & $37.24^{\mathrm{a}} \pm 2.38$ & $38.58^{\mathrm{a}} \pm 1.17$ & $34.39^{\mathrm{b}} \pm 3.35$ & $33.65^{\mathrm{b}} \pm 2.51$ \\
& $3 \mathrm{~d}$ PM & $40.81^{\mathrm{a}} \pm 0.73$ & $40.88^{\mathrm{a}} \pm 1.49$ & $36.67^{\mathrm{b}} \pm 1.68$ & $36.91^{\mathrm{b}} \pm 1.51$ \\
& $7 \mathrm{~d}$ PM & $40.85^{\mathrm{a}} \pm 0.31$ & $40.33^{\mathrm{a}} \pm 0.18$ & $37.82^{\mathrm{b}} \pm 2.26$ & $37.27^{\mathrm{b}} \pm 2.38$ \\
$\mathrm{a}^{*}$ & $1 \mathrm{~d}$ PM & $13.55^{\mathrm{a}} \pm 2.60$ & $13.13^{\mathrm{a}} \pm 1.65$ & $14.50^{\mathrm{a}} \pm 1.93$ & $13.90^{\mathrm{a}} \pm 1.46$ \\
& $3 \mathrm{~d}$ PM & $15.38^{\mathrm{a}} \pm 1.26$ & $16.05^{\mathrm{a}} \pm 2.40$ & $16.20^{\mathrm{a}} \pm 0.54$ & $16.84^{\mathrm{a}} \pm 1.02$ \\
& $7 \mathrm{~d}$ PM & $16.23^{\mathrm{a}} \pm 1.50$ & $17.39^{\mathrm{a}} \pm 2.33$ & $18.82^{\mathrm{a}} \pm 2.01$ & $17.76^{\mathrm{a}} \pm 1.81$ \\
$\mathrm{~b}^{*}$ & $1 \mathrm{~d}$ PM & $11.89^{\mathrm{a}} \pm 1.98$ & $11.68^{\mathrm{a}} \pm 0.59$ & $10.91^{\mathrm{a}} \pm 1.69$ & $10.59^{\mathrm{a}} \pm 1.24$ \\
& $3 \mathrm{~d}$ PM & $14.24^{\mathrm{a}} \pm 0.29$ & $14.58^{\mathrm{a}} \pm 0.77$ & $12.83^{\mathrm{a}} \pm 0.23$ & $13.29^{\mathrm{a}} \pm 0.84$ \\
& $7 \mathrm{~d}$ PM & $14.96^{\mathrm{a}} \pm 0.79$ & $15.25^{\mathrm{a}} \pm 1.33$ & $14.76^{\mathrm{a}} \pm 2.78$ & $14.29^{\mathrm{a}} \pm 1.81$ \\
\hline
\end{tabular}

Different letters in the same row indicate a significant difference $(\mathrm{p}<0.05)$. CC\&ES: carcasses which were conventionally chilled and electrically stimulated after slaughter; RC\&ES: carcasses which were rapidly chilled and electrically stimulated after slaughter; CC\&NS: carcasses which were conventionally chilled and not electrically stimulated after slaughter; RC\&NS: carcasses which were rapidly chilled and not electrically stimulated after slaughter. 
reason might be the different breeding or the different animal situations, for example, the different rate of carcass fat coverage. Similar to the present ES results, some literature showed that ES has significant effect on L*, resulting in brighter meat color that persisted until 6 days, and they proposed that ES could be a color enhancing treatment while applied with RC (Janz et al., 2001; Aalhus et al., 1994). The increased free water increases reflectance, which accounts in part for the brighter appearance of the meat.

\section{Shear force}

Statistical results showed that $\mathrm{RC}$ increased shear force values at $1 \mathrm{~d}, 3 \mathrm{~d}$ postmortem $(\mathrm{p}<0.05)$, while there was no significant differences at $7 \mathrm{~d}$ postmortem $(\mathrm{p}>0.05)$. However, ES decreased shear force at $1 \mathrm{~d}, 3 \mathrm{~d}$ and $7 \mathrm{~d}$ $(p<0.05)$. The shear force values of the four treatments (Figure 1) all decreased with postmortem aging (from $1 \mathrm{~d}$ to $7 \mathrm{~d}$ postmortem), and the average shear force values of the four group, which are conventionally chilled and electrically stimulated (CC\&ES), rapidly chilled and electrically stimulated (RC\&ES), conventionally chilled and not electrically stimulated (CC\&NS), rapidly chilled and electrically stimulated (RC\&NS) were decreased by $38 \%, 42 \%, 21 \%, 24 \%$, respectively. So it can be concluded that RC decreased beef tenderness at early postmortem, and ES not only reduce the detrimental effect of $\mathrm{RC}$, but further enhanced beef tenderness.

Rapid chilling can improve efficiency and facilitate price competition (McGinnisa et al., 1994; Joseph, 1996; Aalhus et al., 2002) and was evaluated by many companies, but its effect on tenderness has not reached a consistent conclusion. The effect of RC on shear force in this study was similar to the research made by White et al. (2006b), it was that RC had no permanent effect on tenderness and the detriment effect of RC could be overcome by postmortem aging.

In the present study, the result agrees with these reports that ES improves beef tenderness (Olsson et al., 1994; Polidori et al., 1999; White et al., 2006a). However, other studies have reported that the application of ES had no significant effect on beef tenderness (Hildrum et al., 1999). These conflicting results may be explained by differences in the status of the animals and the different stimulation methods.

\section{Desmin}

The rate of desmin degradation was affected by the chilling process and ES during postmortem storage (Figure 2). Desmin from all four samples was degraded at different degradation rates during the postmortem aging process.

At $2 \mathrm{~h}$ postmortem, the intact desmin band $(55-\mathrm{kDa})$ was not degraded, and there was no critical difference between ES (lane 1) and NS (lane 2). At $1 \mathrm{~d}$ postmortem, the desmin began to degrade in CC\&ES (lane 3) and CC\&NS (lane 5), and degrade faster in the CC\&ES (lane 3) sample. However, there was no detectable degradation in $\mathrm{RC}$ treated samples (lane 4,6) at $1 \mathrm{~d}$ postmortem. Therefore, it is clear that RC delayed desmin degradation and ES increased it. At $3 \mathrm{~d}$ postmortem, desmin showed further degradation in CC\&ES (lane 7) and CC\&NS (lane 9); however, it seems that there were no changes in RC-treated samples (lane 8,10$)$ at $3 \mathrm{~d}$ postmortem compared with that (lane 4,6 ) at $1 \mathrm{~d}$ postmortem. At $7 \mathrm{~d}$ postmortem, two light

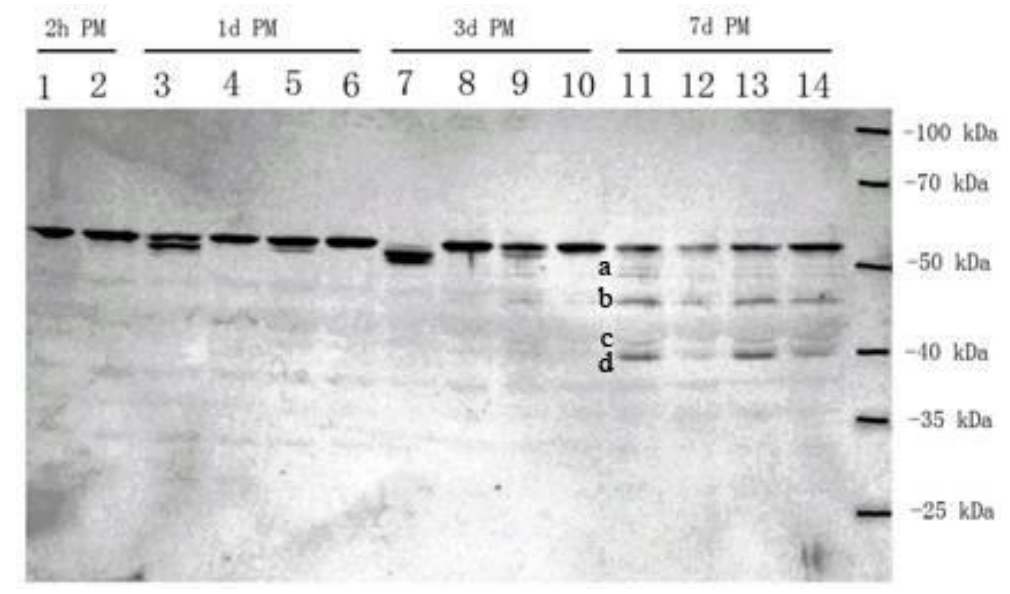

Figure 2. Western blots prepared from $12.5 \%$ gel of samples during postmortem storage and labeled with desmin mono-colonal antibodies. CC\&ES: carcasses which were conventionally chilled and electrically stimulated after slaughter; RC\&ES: carcasses which were rapidly chilled and electrically stimulated after slaughter; CC\&NS: carcasses which were conventionally chilled and not electrically stimulated after slaughter; RC\&NS: carcasses which were rapidly chilled and not electrically stimulated after slaughter. Lane 1 show ES; lane 2 show NS; lanes 3, 7, and 11 show CC\&ES; lanes 4, 8, and 12 show RC\&ES; lanes 5, 9, and 13 show CC\&NS; lanes 6, 10, and 14 show RC\&NS. The letters a, b, c, d mark the key degraded bands 50-kDa (band a), 46-kDa (band b), 41-kDa (band c) and 40-kDa (band d) in the figure. 
degradation bands migrating at approximately 50-kDa (band a) and 41-kDa (band c) appeared, and two dense degradation bands at approximately $46-\mathrm{kDa}$ (band b) and 40-kDa (band d) appeared separately.

Desmin is one of the transversely running elements that link adjacent myofibrils together, and its degradation causes the loss of transversal alignment of the sarcomeres (Rhee et al., 2000). Thus the degradation of desmin can possibly affect the development of tenderness (Ho et al., 1996; Huff Lonergan et al., 2010). Ho et al. (1996) recognized a 38$\mathrm{kDa}$ band in the bovine longissimus muscle aged $7 \mathrm{~d}$ by the antibody that was consistently more heavily labeled in the ES samples at $7 \mathrm{~d}, 14 \mathrm{~d}$, and $28 \mathrm{~d}$ postmortem than that in the NS samples. The $38-\mathrm{kDa}$ band is in all probability the $40-\mathrm{kDa}$ band in the present study. In contrast to Ho et al. (1996), it seems that ES had limited effect on desmin that has been aged for $7 \mathrm{~d}$, which conflicted to the results of shear force. This result indicated that mechanical disruption may be a factor associated with improved tenderness in electrically stimulated muscle (Ho et al., 1997).

\section{Troponin-T}

At $2 \mathrm{~h}$ postmortem, the degradation of troponin- $\mathrm{T}$ and the appearance of the $30-\mathrm{kDa}$ degradation band (band e) were detected (lane 1,2) by Western blotting (Figure 3 ). At $1 \mathrm{~d}$ postmortem, the density of the $30-\mathrm{kDa}$ band in the CC\& ES sample (lane 3) increased faster than the other three samples (lane 4, 5, 6), and the RC treatment clearly delayed the degradation of troponin- $\mathrm{T}$. At $3 \mathrm{~d}$ postmortem, the density of the $30-\mathrm{kDa}$ band increased compared with that at $1 \mathrm{~d}$, especially in RC-treated samples (lane 8, 10). However, the treatment with $\mathrm{RC}$ delayed the degradation of troponin-
T compared with the treatment with $\mathrm{CC}$ both in ES and NS samples at $3 \mathrm{~d}$ postmortem (compare lane 7 with lane 8, lane 9 with lane 10, Figure 3). Four degradation bands appeared at approximately 28-kDa (band f), 24-kDa (band g), 23-kDa (band h), and 22-kDa (band i) at $3 \mathrm{~d}$ postmortem, and $\mathrm{RC}$ treatment decreased the density of degradation bands in both ES and NS samples (compare lane 7 with lane 8 , lane 9 with lane 10, Figure 3).

At $7 \mathrm{~d}$ postmortem, the effects of both RC and ES treatments on the degradation of troponin-T decreased and the density of the $30-\mathrm{kDa}$ band seemed similar. The $23-\mathrm{kDa}$ band was degraded into two bands, and the density of the $22-\mathrm{kDa}$ band became much denser. Additionally, two other dense bands that were approximately $20-\mathrm{kDa}$ (band j), 16$\mathrm{kDa}$ (band k) appeared. The density of 22-kDa (band i), 20$\mathrm{kDa}$ (band $\mathrm{j}$ ) and 16-kDa (band $\mathrm{k}$ ) degradation bands were CC\&ES $>$ CC\&NS $>$ RC\&ES $>$ RC\&NS. The results indicated that RC delayed the rate of proteolysis, while ES accelerated it. So it can be concluded that if RC processing is applied, ES combination is recommended.

Huff Lonergan et al. (1996) also found that increased postmortem time was associated with the appearance of the two major bands of approximately $30-\mathrm{kDa}$ and $28-\mathrm{kDa}$, which were labeled with monoclonal antibodies of troponin-T. As the results of troponin-T degradation, the appearance of the $30-\mathrm{kDa}$ component was proposed to be an indicator for proteolysis (Macbride and Parrish, 1977; Olson and Parrish, 1977; Ho et al., 1994; White et al., 2006a). Huff Lonergan et al. (2010) also showed that the appearance of the $30-\mathrm{kDa}$ and $28-\mathrm{kDa}$ bands in the myofibril was strongly related to the shear force. Olson et al. (1977) showed that the intensity of the $30-\mathrm{kDa}$ component

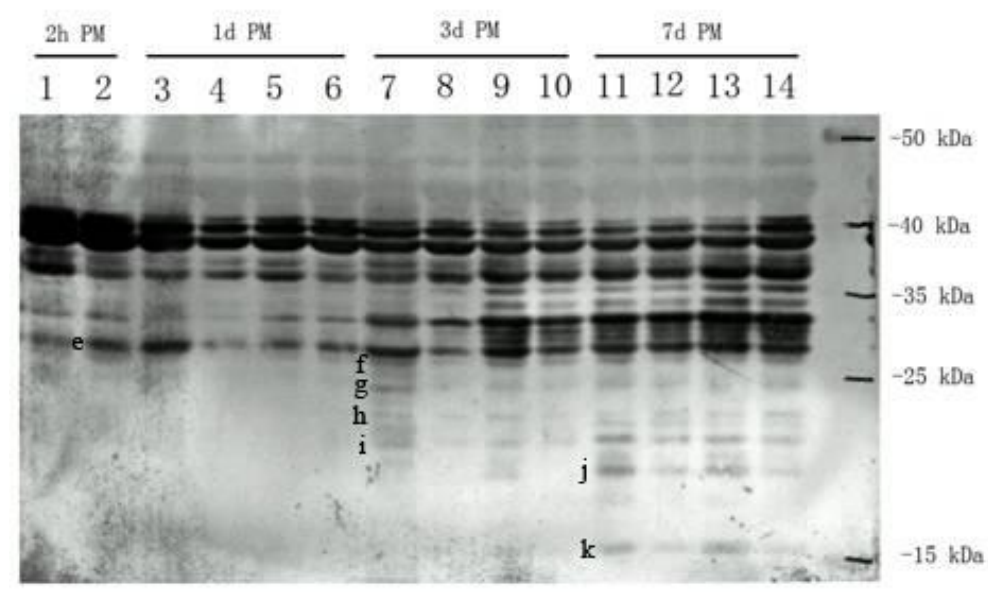

Figure 3. Western blots prepared from $12.5 \%$ gel of samples during postmortem storage and labeled with troponin-T mono-colonal antibodies. CC\&ES: carcasses which were conventionally chilled and electrically stimulated after slaughter; RC\&ES: carcasses which were rapidly chilled and electrically stimulated after slaughter; CC\&NS: carcasses which were conventionally chilled and not electrically stimulated after slaughter; RC\&NS: carcasses which were rapidly chilled and not electrically stimulated after slaughter. Lane 1 show ES; lane 2 show NS; lanes 3, 7, and 11 show CC\&ES; lanes 4, 8, and 12 show RC\&ES; lanes 5, 9, and 13 show CC\&NS; lanes 6, 10, and 14 show RC\&NS. The letters e, f, g, h, I, j, k mark the key degraded bands 30-kDa (band e), 28-kDa (band f), 24-kDa (band g), 23-kDa (band h), 22-kDa (band i) and 20-kDa (band j) 16-kDa (band k) in the figure. 
corresponds to the tenderness level of the steaks and proposed that the intensity of the $30-\mathrm{kDa}$ component is a useful index of tenderness. In the present study, the density of the $30-\mathrm{kDa}$ band was delayed by the RC treatment and increased by the ES treatment until $3 \mathrm{~d}$ postmortem. Previous researches also concluded that low temperature conditions delay the degradation of troponin-T (Hwang et al., 2004; White et al., 2006b). However, it appeared that rapidly and slowly chilled muscles underwent proteolysis to the same extent at $21 \mathrm{~d}$ postmortem, and this study revealed that the early postmortem conditions influenced the rate but not the extent of proteolysis during ageing at $2^{\circ} \mathrm{C}$ for 21 days (White et al., 2006b; White et al., 2006c). Therefore, $\mathrm{RC}$ and ES treatments possibly play an important role in the degradation of troponin- $\mathrm{T}$ and influence tenderness especially at the early postmortem stage. However, in contrast to the present study, White et al. (2006a) found that ES did not appear to have a positive effect on proteolysis as monitored by qualitative SDS-PAGE. Some literatures also reported that ES increased the degradation of desmin and troponin-T in Angus $\times$ Jersey longissimus muscle, but had no effect on degradation of desmin and troponin-T in Bos indicus Crossbred Cattle (Ho et al., 1996; Ho et al., 1997). These differences may due to the different detect methods and breeds of cattle.

\section{DISCUSSION}

Chilling rate is quite critical because too slow or too fast chilling of beef can result in an inferior meat quality (Van Moeseke et al., 2001). The early postmortem chilling rate influences beef tenderness by changing sarcomere length (Locker and Hagyard, 1963; Marsh and Leet, 1966; Wheeler and Koomaraie, 1999; Hwang et al., 2004; White et al., 2006c), affecting enzyme activity (Joseph, 1996; Hwang et al., 2004) and physical restraint (Joseph, 1996; Van Moeseke et al., 2001).

Commercial chilling regimes have been designed to try to avoid carcass temperatures below $10^{\circ} \mathrm{C}$ within the first $10 \mathrm{~h}$ postmortem to prevent toughening (Joseph, 1996; Aalhus et al., 2002). Also several studies proposed that meat reaching rigor mortis at $15^{\circ} \mathrm{C}$ result in optimum tenderization (Geesink et al., 2000; Hwang et al., 2003). Aalhus et al. (2002) found that carcass chilling at $-20^{\circ} \mathrm{C}$ tended to increase shear force values in the longissimus thoracis at $1 \mathrm{~d}$ postmortem and after $21 \mathrm{~d}$ of postmortem aging, but there were no significant effect on semimembranosus; Carcass chilling at $-35^{\circ} \mathrm{C}$ for $10 \mathrm{~h}$ could produce more tender beef at $6 \mathrm{~d}$ postmortem and the differences disappeared with extended postmortem aging to $21 \mathrm{~d}$ (Aalhus et al., 2002). And other reports also indicated that very fast chilling could result in improvements in tenderness (Davey and Garnett, 1980; Bowling et al., 1987;
Sheridan, 1990). Proteolysis and mechanical restraint brought on by surface freezing are considered to be the reasons to produce tender beef (Joseph, 1996; Aalhus et al., 2002).

Considering all literatures cited above, we believe that if factors, which can improve tenderness, play a dominant role and can overcome the detriment effect, the tenderness will be improved. But whether a chilling rate will increase or decrease the meat tenderness and the mechanism of effects on tenderness need further research. Furthermore, animal situation (genotypic variations, pre-slaughter transport and handling, carcass weight, back fat, anatomical muscle site) should be considered besides chilling rate when investigating beef tenderness.

In the present study, troponin- $\mathrm{T}$ began to degrade and the $30-\mathrm{kDa}$ polypeptide began to appear at $2 \mathrm{~h}$ postmortem. In support, Koohmaraie et al. (1987) stated that tenderization begins soon after exsanguination. Although Wheeler and Koohmaraie (1994) proposed that a sufficient amount of proteolysis may have occurred by $24 \mathrm{~h}$ postmortem to affect tenderness, they did not detect the 28 to $32 \mathrm{kDa}$ degradation products until $12 \mathrm{~h}$ postmortem and did not detect any desmin or troponin-T degradation until $24 \mathrm{~h}$ postmortem by SDS-PAGE. Compared to SDS-PAGE, the western blotting antibody detection method might be more sensitive. Thus, using western bolting methods in this study can detect the degradation of troponin- $\mathrm{T}$ in $2 \mathrm{~h}$ postmortem.

Western blotting detected troponin-T degradation at $2 \mathrm{~h}$ postmortem, but did not detect desmin degradation until $1 \mathrm{~d}$ postmortem. Therefore, the degradation of troponin- $\mathrm{T}$ was observed to be earlier than the degradation of desmin, and it may be concluded that troponin- $T$ can be used as a better indicator for the start of tenderization process in the early stage. In the present study, there are some small peptides degradation bands appeared and these peptides may also be related to shear force, similar to the $30 \mathrm{kDa}$ polypeptide. Furthermore, tenderness improved along with the cytoskeletal protein degradation, but they are not completely consistent. So the beef postmortem aging may contain some other mechanisms and need further research.

This study reveals that cytoskeletal proteins can be degraded during postmortem aging, and the results agree with previous studies which showed that beef tenderness increases with extended postmortem aging time. Interestingly, in contrast to the highest shear force at $24 \mathrm{~h}$ postmortem (Wheeler et al., 1994), the extent of desmin and troponin- $\mathrm{T}$ degradation at $24 \mathrm{~h}$ postmortem was greater than that at $2 \mathrm{~h}$ postmortem, so it seems that the tenderness was affected by other factors at early postmortem. Some studies revealed that tenderness varies depending upon the rigor shortening or the degradation of muscle proteins by proteases (Miller et al., 2001; Savell et al., 2005; White et 
al., 2006a). Some studies indicated that the sarcomere length determines tenderness before extensive proteolysis (Wheeler et al., 1994; Hwang et al., 2004). So this study confirmed the tenderness at $24 \mathrm{~h}$ postmortem is not determined by cytoskeletal proteins degradation, and it is assumed that other factors such as sarcomere length are the major determinants, just as the above reports made by Wheeler et al. (1994) and Hwang et al. (2004).

\section{CONCLUSIONS}

$\mathrm{RC}$ decreases beef tenderness at $1 \mathrm{~d}, 3 \mathrm{~d}$ postmortem, but not deteriorates meat color. ES can improve meat lightness and beef tenderness at $1 \mathrm{~d}, 3 \mathrm{~d}, 7 \mathrm{~d}$ postmortem. The degradation rate of desmin and troponin- $T$ were delayed by RC and increased by ES. Combination of RC and ES can not only accelerate postmortem aging rate, but further improve beef tenderness. So combination of RC and ES was recommended to increase production rate and improve beef quality.

\section{ACKNOWLEDGEMENTS}

The work was supported by the CARS-38 from Ministry of Agriculture of the People's Republic of China and a national non-profit project (industry) (200903012).

\section{REFERENCES}

Aalhus, J. L., S. D. M. Jones, S. Lutz, D. R. Best and W. M. Robertson. 1994. The efficacy of high and low voltage electrical stimulation under different chilling regimes. Can. J. Anim. Sci. 74:433-442.

Aalhus, J. L., W. M. Robertson, M. E. R. Dugan and D. R. Best. 2002. Very fast chilling of beef carcasses. Can. J. Anim. Sci. 82:59-67.

Bowling, R. A., T. R. Dutson, G. C. Smith and J. W. Savell. 1987. Effects of cryogenic chilling on beef carcass grade, shrinkage and palatability characteristics. Meat Sci. 21:67-72.

Davey, C. L. and K. J. Garnett. 1980. Rapid freezing, frozen storage and the tenderness of lamb. Meat Sci. 4:319-322.

Geesink, G. H., A. D. Bekhit and R. Bickerstaffe. 2000. Rigor temperature and meat quality characteristics of lamb longissimus muscle. J. Anim. Sci. 78:2842-2848.

Hildrum, K. I., M. Solvang, B. N. Nilsen, T. Frøystein and J. Berg. 1999. Combined effects of chilling rate, low voltage electrical stimulation and freezing on sensory properties of bovine $M$. longissimus dorsi. Meat Sci. 52:1-7.

Ho, C. Y., M. H. Stromer and R. M. Robson. 1994. Identification of the $30 \mathrm{kDa}$ polypeptide in postmortem skeletal muscle as a degradation product of troponin-T. Biochimie 76:369-375.

Ho, C. Y., M. H. Stromer and R. M. Robson. 1996. Effect of electrical stimulation on postmortem titin, nebulin, desmin, and troponin- $\mathrm{T}$ degradation and ultrastructural changes in bovine longissimus muscle. J. Anim. Sci. 74:1563-1575.

Ho, C. Y., M. H. Stromer, G. Rouse and R. M. Robson. 1997.
Effects of electrical stimulation and postmortem storage on changes in titin, nebulin, desmin, troponin-T, and muscle ultrastructure in Bos indicus crossbred cattle. J. Anim. Sci. 75: 366-376.

Huff Lonergan, E., T. Mitsuhashi, F. C. Parrish Jr and R. M. Robson. 1996. Sodium dodecyl sulfate-polyacrylamide gel electrophoresis and western blotting comparisons of purified myofibrils and whole muscle preparations for evaluating titin and nebulin in postmortem bovine muscle. J. Anim. Sci. 74: 779-785.

Huff Lonergan, E., W. Zhang and S. M. Lonergan. 2010. Biochemistry of postmortem muscle-Lessons on mechanisms of meat tenderization. Meat Sci. 86:184-195.

Hwang, I. H., B. Y. Park, S. H. Cho and J. M. Lee. 2004. Effects of muscle shortening and proteolysis on Warner-Bratzler shear force in beef longissimus and semitendinosus. Meat Sci. 68: 497-505.

Janz, J. A. M., J. L. Aalhus and M. A. Price. 2001. Blast chilling and low voltage electrical stimulation influences on bison (Bison bison bison) meat quality. Meat Sci. 57:403-411.

Joseph, R. L. 1996. Very fast chilling of beef and tenderness-a report from an EU concerted action. Meat Sci. 43(Supplement 1):217-227.

Koohmaraie, M., S. C. Seidemann, J. E. Schollmeyer, T. R. Dutson and J. D. Crouse. 1987. Effect of post-mortem storage on $\mathrm{Ca++-dependent} \mathrm{proteases,} \mathrm{their} \mathrm{inhibitor} \mathrm{and} \mathrm{myofibril}$ fragmentation. Meat Sci. 19:187-196.

Li, C. B., Y. J. Chen, X. L. Xu, M. Huang, T. J. Hu and G. H. Zhou. 2006. Effects of low-voltage electrical stimulation and rapid chilling on meat quality characteristics of Chinese Yellow crossbred bulls. Meat Sci. 72:9-17.

Locker, R. H. and C. J. Hagyard. 1963. A cold shortening effect in beef muscles. J. Sci. Food Agric. 14:787-793.

Luo, X., Y. Zhu and G. H. Zhou. 2008. Electron microscopy of contractile bands in low voltage electrical stimulation beef. Meat Sci. 80:948-951.

Macbride, M. A. and F. C. Parrish. 1977. The 30,000-dalton component of tender bovine longissimus muscle. J. Food Sci. 42:1627-1629.

Marsh, B. B. and N. G. Leet. 1966. Studies in Meat Tenderness. III. The effects of cold shortening on tenderness. J. Food Sci. 31:450-459.

McGinnisa, D. S., J. L. Aalhusa, B. Chabota, C. Gariépyb and S. D. M. Jonesa. 1994. A modified hot processing strategy for beef: reduced electrical energy consumption in carcass chilling. Food Res. Int. 27:527-535.

Miller, M. F., M. A. Carr, C. B. Ramsey, K. L. Crockett and L. C. Hoover. 2001. Consumer thresholds for establishing the value of beef tenderness. J. Anim. Sci. 79:3062-3068.

Olson, D. G. and F. C. Parrish. 1977. Relationship of myofibril fragmentation index to measures of beef steak tenderness. J. Food Sci. 42:506-509.

Olsson, U., C. Hertzman and E. Tornburg. 1994. The influence of low temperature, type of muscle and electrical stimulation on the course of rigor mortis, ageing and tenderness of beef muscles. Meat Sci. 37:115-131.

Polidori, P., S. Lee, R. G. Kauffman and B. B. Marsh. 1999. Low voltage electrical stimulation of lamb carcasses: effects on meat quality. Meat Sci. 53:179-182. 
Rhee, M. S., Y. C. Ryu, J. Y. Imm and B. C. Kim. 2000. Combination of low voltage electrical stimulation and early postmortem temperature conditioning on degradation of myofibrillar proteins in Korean native cattle (Hanwoo). Meat Sci. 55:391-396.

Savell, J. W., S. L. Mueller and B. E. Baird. 2005. The chilling of carcasses. Meat Sci. 70:449-459.

Sheridan, J. J. 1990. The ultra-rapid chilling of lamb carcasses. Meat Sci. 28:31-50.

Sun, Q. L., X. Luo, Y. W. Mao and Y. M. Zhang. 2008. Effect of electrical stimulation and delay chilling on the degradation of the Troponin-T from myofibrillar in the post slaughter beef. Transactions of the CSAE 24:262-266.

Van Moeseke, W., S. De Smet, E. Claeys and D. Demeyer. 2001. Very fast chilling of beef: effects on meat quality. Meat Sci. 59:31-37.

Wheeler, T. L. and M. Koohmaraie. 1994. Prerigor and postrigor changes in tenderness of ovine longissimus muscle. J. Anim. Sci. 72:1232-1238
Wheeler, T. D. and M. Koomaraie. 1999. The extent of proteolysis is independent of sarcomere length in lamb longissimus and psoas major. J. Anim. Sci. 77:2444-2451.

White, A., A. O'Sullivan, D. J. Troy and E. E. O'Neill. 2006 a. Effects of electrical stimulation, chilling temperature and hotboning on the tenderness of bovine muscles. Meat Sci. 73: 196-203.

White, A., A. O'Sullivan, D. J. Troy and E. E. O'Neill. 2006 b. Manipulation of the pre-rigor glycolytic behaviour of bovine M. longissimus dorsi in order to identify causes of inconsistencies in tenderness. Meat Sci. 73:151-156.

White, A., A. O’Sullivan, E. E. O’Neill and D. J. Troy. $2006 \mathrm{c}$. Manipulation of the pre-rigor phase to investigate the significance of proteolysis and sarcomere length in determining the tenderness of bovine $M$. longissimus dorsi. Meat Sci. 73:204-208 